๑ Laboratorium: журнал социальных исследований. 2019. 11(3):152-158

\title{
Варвара Склез
}

\section{Алейда Ассман. Забвение истории - одержимость историей. М.: Новое лите- ратурное обозрение, 2019. 552 с. ISBN 978-5-4448-1151-1.}

\begin{abstract}
Варвара Склез, Институт этнологии и антропологии Российской Академии наук; Московская высшая школа социальных и экономических наук; университет Уорика. Адрес для переписки: Московская высшая школа социальных и экономических наук, Газетный пер., 3-5, стр.1, Москва, 125009, Россия. varvar.sk@ gmail.com.
\end{abstract}

Рецензия написана в рамках проекта РНФ №19-78-10076.

\author{
это нам не спели \\ вечную память. \\ не про нас \\ ветер на сопках \\ каждую ночь \\ слоняется \\ и рыдает. \\ -Станислав Львовский, \\ «Советские застольные песни»
}

В рецензируемое издание вошли три работы Алейды Ассман: книга «Формы забвения» (2016), статья «1998 - между историей и памятью» (1999) и книга «История в памяти. От индивидуального опыта к публичному инсценированию» (2007). Книга «Формы забвения» посвящена понятию «забвение», выработке терминологического аппарата для его анализа и рассмотрению различных случаев забвения в историческом и современном контекстах. В «1998 - между историей и памятью» Ассман прослеживает изменения истории памяти в Германии на примере состоявшейся в 1998 году дискуссии между писателем Мартином Вальзером и председателем Центрального совета евреев в Германии Игнацем Бубисом. Книга «История в памяти. От индивидуального опыта к публичному инсценированию» посвящена многообразию способов обращения к истории за пределами академической науки.

Если до этого издания русскоязычный читатель был в большей степени знаком с Ассман как исследовательницей немецкой мемориальной культуры, то «Формы забвения», первая из включенных в это издание работ, принципиально строится на анализе очень разных как по своей географии, так и масштабу кейсов. По этой причине представленный здесь обзор будет посвящен именно этой книге.

В предисловии Ассман отказывается от дихотомии памятования и забвения. Она иллюстрирует их неразрывную связь на примере барочной эмблемы, изображающей открытую книгу, лежащую на облаке, из которого идет дождь, символизи- 
рующий исходящие из книги знания. Как малая часть этих капель попадает в сосуд с узким горлом, изображенный под книгой, так лишь часть нашего опыта ухватывается памятью. В такой перспективе задача книги выглядит очень амбициозной: означает ли изучение забвения исследование всего массива историй, образов и опытов, не оставивших воспоминаний? Думаю, что ответ на этот вопрос напрашивается при взгляде на самые первые шаги memory studies как дисциплины. Так, Пьер Нора (1999) во вступлении к «Местам памяти» утверждал, что в пределе каждый человек теперь имеет право на историю. Впоследствии многие теоретики истории отмечали ситуацию, в которой прошлое становится все более проницаемым для тех, кто действует в настоящем, все чаще обращающихся к нему, выносящих на свет забытые истории, проблематизирующих существующие нарративы, легитимизирующих свои интересы (Артог 2008; Гумбрехт 2007; Нора 2005). «0держимость прошлым», ставшую общим местом в этом направлении исследований, можно рассматривать и как кризис представлений о будущем, своеобразную растерянность перед ним, и как нарастающую необходимость разноуровневой рефлексии о том, что уже произошло с нашим миром. В этом смысле интерес академических исследователей к забвению можно понять как симптом осознания того, какой огромный массив опыта остается за пределами каждого прилива памяти. Вопрос о том, что забыто, всякий раз оказывается обратной стороной того, что вспомнено. Эта предпосылка позволяет Ассман снять методологические вопросы, которые могут возникнуть при работе с забвением, определяемым негативно. Если память понимается через соприсутствие в ней памятования и забвения, то возможно обнаружить следы последнего.

В этой перспективе внимание к забвению как бы подсвечивает память и позволяет увидеть сложность ее ткани, процессы ее постоянного становления. Нельзя не отметить, что в такой формулировке очертания памяти как объекта исследования отчасти размываются. В первой из переведенных на русский язык книге «Длинная тень прошлого. Мемориальная культура и историческая политика» Ассман отмечала, что «коллективную память» стоит понимать как понятие, пришедшее на смену «идеологии» и ее критическому изучению. В числе ключевых отличий этих двух понятий она отмечает признание обусловленности опыта существующими рамками и образами и связанную с этим необходимость постоянной рефлексии собственных оснований теми, кто говорит о нем и исследует его. В книге «Формы забвения» эта необходимость становится особенно отчетливой. Более того, я рискну предположить, что именно в сложности этой работы (и требуемого для нее уровня эмпатии) и заключается главная драма описываемой Ассман сцены современной памяти.

Автор выделяет семь форм забвения, опираясь на работы Даниэля Шактера (Schacter 1999) и Пола Коннертона (Connerton 2008, 2009). Автоматическое забвение, наряду со сберегающим и селективным, она относит к ценностно нейтральным формам. Забвение здесь понимается как фильтр, который неизбежно просеивает содержимое опыта. Рассматривая первую из выделяемых семи форм забвения - автоматическое забвение, - она отмечает, что разница между «естественными» и человеческими процессами заключается в наличии у людей выбора 
между памятованием и забвением, что требует этических решений. Особенно она подчеркивает эту необходимость в случае травматического прошлого.

Если автоматическое забвение ассоциируется скорее с неизбежным течением времени и связанными с ним изменениями, то сберегающее забвение акцентирует накопительный потенциал общества, его способность сохранять вещи и тексты от окончательного забвения через архивы и подобные им механизмы. Ассман подчеркивает, что и в этом случае (демократическое) общество должно вырабатывать критерии, позволяющие отделить «существенное от несущественного» (с. 39).0писывая селективное забвение, Ассман проблематизирует вопрос о том, как именно вырабатываются эти критерии, рассматривая как когнитивные, так и социальные механизмы забвения. Забвение здесь особенно отчетливо предстает конституирующим механизмом для памяти. Этическое напряжение, содержащееся в понятии забвения, хорошо передает отсылка к идеям Ханны Арендт, которая соотнесла активную деятельность с возможностью прощения и забвения ее негативных последствий (с. 41-42). Именно в этом разделе Ассман говорит о включении современными западными странами точки зрения жертв в национальные нарративы.

К негативным формам забвения Ассман относит карающее, репрессивное и охранительное, совиновное. Забвение здесь понимается как средство удержания и поддержания власти. Положительные же формы забвения - конструктивное и терапевтическое - акцентируют трудную работу по преодолению прошлых страданий и утрат, по мысли Гуго фон Гофмансталя, «существование на границе между памятованием и забвением» (с. 51). Если конструктивная форма забвения подчеркивает необходимость дистанции по отношению к прошлому и фактически отождествляется со сменой оптики, которую делает возможной эта дистанция, то терапевтическое забвение означает осуществленную проработку трудных эпизодов прошлого и их включение в совместную память (и, таким образом, их преодоление) для построения общего будущего. Интересно, что, рассматривая последнюю из этих форм, Ассман ссылается на Авишая Маргалита, утверждавшего необходимость стирания памяти, «эмоционально воскрешающей пережитое событие, а не воспоминание о самом событии» (с. 58).

Каждый из разделов второй главы книги «Семь примеров» не столько иллюстрирует предложенную типологизацию, сколько предлагает различные линии сборки истории памяти. Так, первый раздел посвящен памятникам и ставит рядом три существенно отличающихся как по типу, так и по хронологии кейса: эссе Роберта Музиля «Памятники», перенос памятника Алеше из центра Таллина на солдатское кладбище и дискуссии о статуе Карлу Люгеру в Вене. Каждый из этих примеров проблематизирует различные аспекты динамики памятования и забвения. Если эссе Музиля фиксирует «невидимость» памятников, вписанных в повседневный ландшафт городов, а автор даже делает вывод об их несовременности, то скандал, последовавший за переносом памятника Алеше, показывает, как сильна была его символическая значимость для населения города. История с памятником Люгеру, долгое время остававшегося «невидимым» (по Музилю) и вдруг ставшего центром общественной дискуссии после объявления Венским университетом конкурса на переделку монумента в Австрийский мемориал против антисе- 
митизма и расизма, работает в этом разделе в качестве примера публичной выработки критериев памятования и забвения. Так, обращение к фигуре Люгера высветило не только его достижения в качестве градоначальника, но и его антисемитские политические позиции. Для Ассман развернувшаяся дискуссия работает в качестве примера общественной рефлексии не только о прошлом места, но и о формах и границах конкретного типа памятования. Победивший на этом конкурсе проект Клеменса Вилидаля, предложившего отклонить статую и цоколь на три градуса вправо, согласно Ассман, указывает на само «наличие проблемы в осмыслении Веной своего антисемитского прошлого» (с. 73). Таким образом, три примера и фиксируют различные исторические представления о соотношении памятования и забвения и взаимно проясняют друг друга. Размышления Музиля подпитывают рефлексию Ассман о бытовании памятников: их устойчивость и материальность, отмеченные им, оказываются метафорой аффективного потенциала, который они заключают в себе и который активизируется при изменении контекста и должен быть учтен в современных практиках коммеморации.

Второй раздел этой части задает гораздо более широкий масштаб и посвящен фигуре Владимира Ленина в ГДР и постсоциалистических странах. Начиная этот раздел (и рифмуя его таким образом с первым) с сюжета о различных способах обращения с памятниками Ленину в Берлине и Киеве, Ассман далее переходит к месту Ленина в памяти постсоветской России, подробно останавливаясь на открытом в 1987 году музее Ленина (сейчас - музей-заповедник «Горки Ленинские»). Два кейса - судьба 19-метрового памятника Ленину, установленного в Берлине в 1970 году, и музея Ленина, - как и кейсы первого раздела демонстрируют соприсутствие памятования и забвения и (возможно, за счет масштаба) расширяют диапазон этих рамок. Так, памятник в Берлине был разобран и закопан в песчаном холме в лесу Мюггельвальд. При этом буквальное погребение памятника не означало его исчезновения из воображения людей. В 2016 году в музее в цитадели Шпандау была открыта экспозиция «Открытие. Берлин и его памятники», в которой откопанная голова Ленина была помещена между другими каменными изображениями персонажей истории города. Музей Ленина же Ассман называет «музеем забвения», который парадоксальным образом продолжает поддерживать память о Ленине в ситуации, когда его фигура потеряла прежнюю символическую значимость. Хотя Ленин в этой перспективе оказывается не нужным для российской национальной памяти, не до конца понятным остается, что говорит об этой памяти анализ парадоксальных форм, в которых он продолжает свое существование. Здесь можно заметить методологическую трудность перехода с масштаба политики памяти к отдельным кейсам. Если тонкий анализ конкретных примеров позволяет увидеть сложность динамики памятования и забвения, то в перспективе анализа политики памяти в современной России эти детали оказываются незначительными. Так, память о Второй мировой войне соотносится Ассман главным образом с «гордостью за победу Сталина над Гитлером» (с. 82), а «Бессмертный полк» рассматривается исключительно как механизм преобразования живой памяти участников исторических событий в долговременную нацио- 
нальную память. Различие мотиваций участников этой практики и ее перформативное измерение оказываются в этой перспективе несущественными ${ }^{1}$.

Следующие разделы еще в большей степени заставляют задуматься о применимости «национальной памяти» как ключевой категории анализа. Примеры, приведенные в этих разделах, разными способами расшатывают эти рамки. В третьем разделе, сформированном вокруг сюжета об уничтожении культурного наследия в Левене, Сараево и Пальмире, Ассман говорит о расширении европейской памяти и необходимости взгляда поверх национальных границ, подобного тому, что сделали возможным некоторые мероприятия в рамках столетнего юбилея Первой мировой войны в 2014 году. Если память об уничтожении библиотеки в Левене сохранилась в самом городе, то в немецкой памяти, по словам Ассман, эта трагедия не оставила следа. Она говорит о необходимости «диалогической памяти», которая позволяет «преобразовать слепые места национальной памяти в историческое зрение» (с. 96). Особенно важным здесь кажется, что примеры в этом разделе не ограничиваются Европейским союзом (Сараево) и географической Европой (Пальмира). Именно Балканы оказываются для Ассман воплощением исторической сложности и насыщенности пространства, в котором запечатлеваются и наслаиваются следы различных эпох, стилей и событий. Ее героем в этом разделе становится сербский архитектор, урбанист-теоретик и эссеист Богдан Богданович, размышлявший в категориях памятования и забвения об уничтожении наследия в результате страшных событий XX века, и именно его теория используется Ассман для локализации временных наслоений в других частях Европы. Тотальное уничтожение культурного наследия понимается Богдановичем как выражение «страха перед сложностью и неисчерпаемостью архитектурного языка прежних эпох и поколений, которых разрушители городов не могут понять, поставить под контроль и покорить» (с. 101). И именно эта сложность, по Ассман, оказывается не нужной тем, кто насаждает «новую национальную память» (с. 102). Более того, в параграфе, посвященном уничтожению Пальмиры Исламским государством, она делает вывод о том, что «инклюзивной концепции человечества, объединяющего все нации и приверженного ценностям всемирного культурного наследия, сегодня больше не существует» (с. 108). И это утверждение с еще большей остротой ставит вопрос о том, как могут вырабатываться рамки памятования и забвения в условиях, когда универсальное больше невозможно. Ответ, который дает на этот вопрос Ассман, делает видимыми конкретные усилия отдельных людей, позволяющие раз за разом преодолевать эту разделенность. К таким примерам относятся увенчавшиеся успехом попытки президента Германии Йоахима Гаука признать совиновность германского рейха в армянском геноциде 1915 года или возвращение памяти о своих предках девочкам, забранным из пеших колонн депортированных армян и выращенным в турецких семьях, осуществляемое самими этими семьями. При этом надо отметить, что в обоих случаях Ассман не избегает подробного описания сопротивления, прежде всего - политического, с которым столкнулись эти усилия.

1 Антропологическая перспектива анализа «Бессмертного полка» представлена в Архипова и др. (2017). 
Следующий раздел соотносит два травматических события, оказавшихся взаимосвязанными в контексте политики памяти на Ближнем Востоке: Холокост и Накбу. Тот факт, что образование Израиля означало изгнание арабов из их домов и городов, сделал два народа нечувствительными по отношению к страданиям друг друга, что нашло отражение в соответствующих национальных нарративах. Примеры отдельных инициатив, призванных заполнить это «слепое пятно» в израильской истории, показывают, что соотнесение национального и локального уровней - это не только методологический вопрос. Так, усилия израильской общественной организации «Зохрот», направленные на возвращение повседневного знания о палестинском прошлом современного израильского ландшафта, столкнулись с принятым в 2011 законом о «Накбе», который криминализировал память об изгнании палестинцев. Называя вслед за Ифатом Гутманом деятельность «Зохорта» контрпамятью, Ассман предполагает, что «подобное "оппозиционное производство знания" ведет скорее к упрочению нынешнего положения вещей» (с. 141). В этой перспективе интересно было бы подумать, какой тип такого производства не ведет к этому упрочению и при этом приводит к реальным переменам. С одной стороны, Ассман утверждает, что «безусловное право палестинцев на возвращение не должно ставить под вопрос существование израильского государства и подрывать его основы» (с. 145). С другой стороны, она говорит о необходимости «расширения» национальной памяти, которую делают возможными отдельные инициативы. Вопрос остается прежним: в какой мере эту память можно называть национальной?

В следующем разделе происходит резкая смена масштаба: от национальных нарративов Ассман переходит к анализу очень локального кейса рецепции судьбы Ханса Роберта Яусса (в том числе факта его службы офицером ваффен-СС) в Университете Констанца. Она реконструирует «долгую историю забвения» Яусса и критически анализирует рамки памяти, которыми были обусловлены ее различные фазы. Этот пример, можно сказать, неудачной проработки прошлого позволяет отчетливо увидеть, насколько проблематичным является процесс выработки таких рамок, которые позволили бы увидеть историю во всей ее сложности, а не воспроизводили бы уже существующие рамки. Более того, он заставляет задуматься о возможной устойчивости подобных рамок: если от современных людей и групп требуется постоянная рефлексия о рамках, определяющих их взгляд на прошлое, могут ли эти рамки стать основанием для формирования идентичностей, и, если да, то каковы очертания этих идентичностей? И что мы имеем в виду под понятием «прошлого», когда говорим об этой постоянной и трудной работе в настоящем?

Часть ответов на перечисленные вопросы мы получаем в заключительном разделе главы, посвященном динамике памятования и забвения в ситуации все более активного развития и распространения интернета. В ситуации, когда накопительные мощности, имеющиеся в нашем распоряжении, возрастают, структура памяти существенно переопределяется и потенциально ставит под вопрос саму возможность забвения. Однако Ассман подчеркивает, что в этой ситуации именно человек принимает решение, как выстроить свою траекторию в этом массиве дан- 
ных. Эта ситуация необходимого выбора особенно отчетливо передает современное напряжение между прошлым и настоящим.

Эта книга буквально пропитана ощущением переполненности памяти. Причем это чувство связано не столько с растущими возможностями сохранения информации, о которых Ассман пишет в последнем разделе, сколько с пониманием множественности забытых, разнообразных и зачастую конфликтных версий прошлого. Нельзя не согласиться с исследовательницей: переполненность прошлым и его повышенная видимость сами по себе не являются угрозой. Настоящим вызовом представляется поиск рамок, в которых возможно примирение этих историй.

\section{СПИСОК ЛИТЕРАТУРЫ}

Артог, Франсуа. 2008. «Порядок времени, режимы историчности». Неприкосновенный запас 3:19-38.

Архипова, Александра, Дмитрий Доронин, Анна Кирзюк, Дарья Радченко, Анна Соколова, Алексей Титков и Елена Югай. 2017. «Война как праздник, праздник как война: перформативная коммеморация Дня Победы». Антропологический форум 33:84-122.

Гумбрехт, Ханс-Ульрих. 2007. «Современная история в настоящем меняющегося хронотопа». Новое литературное обозрение 1:45-50.

Нора, Пьер. 1999. «Между памятью и историей». С. 17-50 в Франция-память, под ред. Пьера Нора, Моны Озуф, Жерара де Пюимежа, Мишеля Винок. СПб.: Издательство Санкт-Петербургского университета.

Нора, Пьер. 2005. «Всемирное торжество памяти». Неприкосновенный заnас 2-3:202-208. Connerton, Paul. 2008. "Seven Types of Forgetting." Memory Studies 1(1):59-71.

Connerton, Paul. 2009. How Modernity Forgets. New York: Cambridge University Press.

Schacter, Daniel L. 1999. "The Seven Sins of Memory: Insights from Psychology and Cognitive Neuroscience." American Psychologist 54(3):182-203. 